\title{
STUDIES ON TENSILE PROPERTIES AT VARIOUS STRAIN RATES AND CORROSION BEHAVIOR OF PEAK-AGED Al-6Si-0.5Mg (-0.5Cu) ALLOYS
}

\author{
Abul Hossain, Fahmida Gulshan and Abu Syed Wais Kurny \\ Department of Materials and Metallurgical Engineering, \\ Bangladesh University of Engineering and Technology, Dhaka-1000, Bangladesh. \\ ah_nuetmmesgfl@live.com \\ (Received: $13^{\text {th }}$ Sept. 2015; Accepted: $26^{\text {th }}$ Mar. 2016; Published on-line: $30^{\text {th }}$ Nov. 2016)
}

\begin{abstract}
This paper focuses on the effect of $\mathrm{Cu}$ additions on the tensile properties of the Al-6Si-0.5 Mg alloy at various strain rates and electrochemical corrosion behavior. The addition of $\mathrm{Cu}$ resulted in an increase in the tensile strength and showed higher strength all over the experimental strain rates. Evaluations of tensile properties at the three different strain rates $\left(10^{-4}, 10^{-3}\right.$ and $10^{-}$ ${ }^{2} \mathrm{~s}^{-1}$ ) showed that they affected the tensile properties significantly. The strength was better at higher strain rate but ductility was poor. Electrochemical Impedance Spectroscopy (EIS) and potentiodynamic polarisation have been used to evaluate the corrosion resistance of $\mathrm{Cu}$-free and $0.5 \mathrm{wt} \% \mathrm{Cu}$ content $\mathrm{Al}-6 \mathrm{Si}-0.5 \mathrm{Mg}$ alloy in a $0.1 \mathrm{M} \mathrm{NaCl}$ solution. The $0.5 \mathrm{wt} \% \mathrm{Cu}$ addition to the $\mathrm{Al}-6 \mathrm{Si}-0.5 \mathrm{Mg}$ alloy showed that $\mathrm{Cu}$ decreased susceptibility to corrosion compared to the $\mathrm{Cu}$ free $\mathrm{Al}-6 \mathrm{Si}-0.5 \mathrm{Mg}$ alloy. The magnitude of the open circuit potential (OCP), corrosion potential ( $\mathrm{E}_{\text {corr }}$ ) and pitting corrosion potential $\left(\mathrm{E}_{\mathrm{pit}}\right)$ of the $\mathrm{Al}-6 \mathrm{Si}-0.5 \mathrm{Mg}$ alloy were shifted to the more noble direction due to the $0.5 \mathrm{wt} \% \mathrm{Cu}$ addition and thermal modification.
\end{abstract}

ABSTRAK: Kajian ini memberi tumpuan kepada kesan penambahan $\mathrm{Cu}$ pada sifat tegangan aloi Al-6Si-0.5 Mg di dalam pelbagai kadar keterikan dan tingkah laku kakisan elektrokimia. Penambahan kepada $\mathrm{Cu}$ mengakibatkan peningkatan dalam kekuatan tegangan dan menunjukkan kekuatan yang lebih tinggi di seluruh kadar keterikan didalam eksperimen. Penilaian ke atas sifat tegangan pada tiga kadar keterikan yang berbeza $\left(10^{-4}, 10^{-3}\right.$ dan $\left.10^{-2} \mathrm{~s}^{-1}\right)$ menunjukkan bahawa ia memberi kesan kepada sifat tegangan dengan ketara. Kekuatannya adalah lebih baik pada kadar terikan yang lebih tinggi tetapi ductility adalah kurang. Eelectrochemical impedance spektroskopi (EIS) dan polarisasi potentiodynamic telah digunakan bagi membuat penilaian terhadap rintangan kakisan bebas $\mathrm{Cu}$ dan $0.5 \mathrm{wt} \%$ kandungan $\mathrm{Cu}$ Al-6Si-0.5Mg aloi dalam 0.1 M larutan $\mathrm{NaCl}$. Penambahan $0.5 \mathrm{wt} \% \mathrm{Cu}$ kepada aloi $\mathrm{Al}-6 \mathrm{Si}-0.5 \mathrm{Mg}$ menunjukkan bahawa $\mathrm{Cu}$ mengurangkan kerentanan untuk kakisan berbanding dengan $\mathrm{Cu}$ bebas aloi Al-6Si-0.5Mg. Magnitud potensi litar terbuka $(\mathrm{OCP})$, potensi kakisan $\left(\mathrm{E}_{\mathrm{corr}}\right)$ dan potensi hakisan pitting $\left(\mathrm{E}_{\mathrm{pit}}\right)$ daripada aloi Al-6Si-0.5Mg telah menunjukkan hasil yang lebih baik kerana penambahan 0.5 wt $\% \mathrm{Cu}$ dan pengubahsuaian haba.

KEYWORDS: Al-6Si-O.5Mg alloy; tensile properties; electrochemical corrosion; SEM

\section{INTRODUCTION}

An excellent aptitude to the casting and forging processes, machinability, corrosion resistance, and high strength-to-weight ratio, which increases performance and fuels economy, make heat treatable aluminium alloys suitable materials for 
various crucial applications in the automotive industry, such as engine blocks, pistons and cylinder heads $[1,2]$. The high strength levels are achieved by the T6 heat treatment that provides strengthening through the precipitation hardening mechanism [3]. T6 heat treatment consists of three fundamental steps: solution, quench, and artificial aging (carried out in furnace). In the solution treatment, the high temperatures promote the homogeneous diffusion of the hardening elements in the matrix. Through the water quench, and subsequent artificial aging, a supersaturated matrix and a precipitation of hardening phases are respectively obtained. In fact, after the quench, the supersaturated matrix forces the constitutional elements to form coherent precipitates reducing the total free energy of the system. These precipitates hinder the dislocation motion resulting in increased yield strength and hardness. However, the final hardness of the alloy results from the heat treatment parameters, such as the time and temperature of the solution treatment, the quenching conditions, and the artificial aging procedure. In the case of Al-Si-Mg casting alloys, the short storage at room temperature between quenching and aging phases, due to the industrial handling of the components, is also one of the crucial parameters affecting the tensile properties of the material [4].

This time, known as "preaging", affects the precipitation sequence of metastable phases that occur during the artificial aging. This sequence, for $\mathrm{Al}-\mathrm{Si}-\mathrm{Mg}$ alloys, can be summarised as follows: $\alpha(\mathrm{sss}) \rightarrow$ zone_GP $\rightarrow \beta{ }^{\prime \prime} \rightarrow \beta{ }^{\prime} \rightarrow \beta\left(\mathrm{Mg}_{2} \mathrm{Si}\right)$ [5]. In it, $\alpha$ (sss) is the supersaturated solid solution, GP zones are coherent Guiner-Preston zones, $\beta$ " is the needle shaped precipitates associated with the peak-aged condition, $\beta$ ' is the rod shaped precipitates that form after $\beta$ " precipitates in the aging sequence, and $\beta$ is the equilibrium phase [3,6]. For $\mathrm{Al}-\mathrm{Si}-\mathrm{Mg}-\mathrm{Cu}$ alloys, the precipitation behaviors are rather complicated and several phases such as $\beta\left(\mathrm{Mg}_{2} \mathrm{Si}\right), \theta\left(\mathrm{CuAl}_{2}\right)$, $\mathrm{S}\left(\mathrm{CuMgAl}_{2}\right)$ or $\mathrm{Q}\left(\mathrm{Cu}_{2} \mathrm{Mg}_{8} \mathrm{Si}_{6} \mathrm{Al}_{5}\right)$ in metastable situations may exist [7-9].

Results of tests on aluminium alloys at different strain-rate levels have been reported by a number of investigators. At room temperature, a very low, yet slightly positive, increase in flow stress with strain rate was reported by [10]. Similar observations regarding rate sensitivity of aluminium alloys, now in tension, were reported by investigating the AA7003-T79 and AA7108-T6 alloys [11]. On the other hand, the flow stress and fracture strain of AA6005-T6 were shown to have rather strong positive strain-rate sensitivity [12].

The alloys containing copper are the least resistant to corrosion; but this can be improved by coating each side of the copper-containing alloy with a thin layer of high purity aluminium, thus gaining a three-ply metal (Alclad). This cladding acts as a mechanical shield and offers sacrificial protection. When aluminium surfaces are exposed to the atmosphere, a thin invisible oxide $\left(\mathrm{Al}_{2} \mathrm{O}_{3}\right)$ skin forms; this protects the metal from further corrosion in many environments. This film protects the metal from further oxidation unless this coating is destroyed, and the material remains fully protected against corrosion [13-14]. A number of studies have been carried out to assess the effect of $\mathrm{Cu}$ content and the distribution of second phase intermetallic particles on the corrosion behavior of $\mathrm{Al}$ alloys. The distribution of $\mathrm{Cu}$ in the microstructure affects the susceptibility to localized corrosion. Intergranular corrosion (IGC) is generally believed to be associated with $\mathrm{Cu}$-containing grain boundary precipitates and the Precipitates Free Zones (PFZ) along grain boundaries. In heat treatable $\mathrm{Al}-\mathrm{Si}-\mathrm{Mg}(-\mathrm{Cu})$ series alloys, the susceptibility to localized corrosion [pitting and/or intergranular (IGC)] and the extent of attack are mainly controlled by the type, amount, and distribution of the precipitates that form in the alloy during any 
thermal or thermomechanical treatment performed during manufacturing processes. The composition of an alloy and its thermal treatment are important to determine the susceptibility of the alloy to corrosion [15-20]. Depending on the composition of the alloy and parameters of the heat treatment process, precipitates form in the bulk of the grain, or in the bulk as well as in the grain boundaries [14,21].

In this work, the authors present a study of the tensile properties at various strain rates and electrochemical corrosion behavior of an $\mathrm{Al}-6 \mathrm{Si}-0.5 \mathrm{Mg}$ alloy with low $\mathrm{Cu}$ content.

\section{EXPERIMENTAL METHODS}

\subsection{Materials}

Aluminium and aluminium A356 alloy, contained in a clay-graphite crucible, were melted in a gas-fired pot furnace. Copper, in sheet form (99.98\% purity), was then added by plunging. Magnesium (99.7\% purity) in the form of ribbons, and packed in an Al-foil, was added to the melt. The final temperature of the melt was maintained at $900 \pm 15{ }^{\circ} \mathrm{C}$. Before casting, the melt was degassed with solid hexachloroethane $\left(\mathrm{C}_{2} \mathrm{H}_{6}\right)$ and homogenized by stirring at $700{ }^{\circ} \mathrm{C}$. Casting was done in a metal mould measuring $15 \mathrm{~mm} \times 150 \mathrm{~mm} \times 300 \mathrm{~mm}$ and preheated to $200{ }^{\circ} \mathrm{C}$. All the alloys were analyzed by wet chemical and spectrochemical methods simultaneously.

\subsection{Heat Treatment}

The cast samples were ground to remove the oxide layer from the surface and were homogenized for 24 hours at $500{ }^{\circ} \mathrm{C}$. Samples for tension tests were prepared from the homogenized plates according to the ASTM standard (Sub-size standard ASTM E8 M-04). The tension test samples were solution-treated at $540{ }^{\circ} \mathrm{C}$ for 120 minutes and quenched in an ice-salt-water solution. The solutionized samples were finally aged at $225^{\circ} \mathrm{C}$ for $1 \mathrm{hr}$ (peak-aged).

\subsection{Tension Tests}

Tensile testing was carried out in an Instron testing machine at three different cross-head speeds: $0.15,1.5$, and $15 \mathrm{~mm} /$ minute, which are equal to the nominal strain rates of $10^{-4}, 10^{-3}$, and $10^{-2} \mathrm{~s}^{-1}$ respectively for each alloy. The averages of three consistent test results were accepted as the tensile value for the corresponding sample. Fractographic observations of the fractured surfaces of selected samples were carried out on a scanning electron microscope (SEM).

\subsection{Potentiodynamic Polarization Measurements}

The peak-aged $\left(225{ }^{\circ} \mathrm{C}\right.$ for $\left.1 \mathrm{hr}\right)$ rectangular samples $(30 \mathrm{~mm} \times 10 \mathrm{~mm} \times 5 \mathrm{~mm})$ were prepared for metallographic observation and subsequent electrochemical test. Deionized water and an analytical reagent grade sodium chloride $(\mathrm{NaCl})$ were used for the preparation of a $0.1 \mathrm{M}$ solution (simulated seawater). All measurements were carried out at room temperature. A computer-controlled Gamry Framework TM Series G 300 ${ }^{\mathrm{TM}}$ and Series G $750^{\mathrm{TM}}$ Potentiostat/Galvanostat/ZRA were used for the electrochemical measurements. The potentiodynamic polarization studies were configured in cells, using three-electrode assembly: a saturated calomel reference electrode, a platinum counter electrode, and the sample in the form of coupons with an exposed area of $0.50 \mathrm{~cm}^{2}$ or $10 \mathrm{~mm} \times 5 \mathrm{~mm}$ as a working electrode. Only one 10 $\mathrm{mm} \times 5 \mathrm{~mm}$ surface was exposed to the test solution, the other surfaces being 
covered with Teflon tape. The system was allowed to establish a steady-state open circuit potential (OCP). The potential range selected was -1 to $+1 \mathrm{~V}$ and measurements were made at a scan rate of $0.50 \mathrm{mV} / \mathrm{s}$. The corrosion current $\left(\mathrm{I}_{\text {corr }}\right)$, corrosion potential $\left(\mathrm{E}_{\mathrm{corr}}\right)$, pitting corrosion potential $\left(\mathrm{E}_{\mathrm{pit}}\right)$, and corrosion rate (mpy) were calculated from the Tafel curve. The tests were carried out at room temperature in solutions containing $0.1 \mathrm{M}$ of $\mathrm{NaCl}$ at a fixed and neutral $\mathrm{pH}$ value. The corroded samples were cleaned in distilled water and examined under an optical light microscope (OLM) and a scanning electron microscope (SEM).

\subsection{Electrochemical Impedance Measurements}

As in the potentiodynamic polarization test, three electrode cell arrangements were also used in the electrochemical impedance measurements. Rectangular samples $(10 \mathrm{~mm} \times 5 \mathrm{~mm})$ were connected with copper wire and adopted as a working electrode. EIS tests were performed in simulated seawater at room temperature over a frequency range of $100 \mathrm{kHz}$ to $0.2 \mathrm{~Hz}$ using a $5 \mathrm{mV}$ amplitude sinusoidal voltage. The $10 \mathrm{~mm} \times 5 \mathrm{~mm}$ sample surface was immersed in simulated seawater (corrosion medium). All the measurements were performed at the open circuit potential (OCP). The test cells were maintained at room temperature and the $\mathrm{NaCl}$ solution was refreshed regularly during the whole test period. The impedance spectra were collected, fitting the experimental results to an equivalent circuit (EC) using the Echem Analyst ${ }^{\mathrm{TM}}$ data analysis software and evaluating the solution resistance $\left(\mathrm{R}_{\mathrm{s}}\right)$, polarization resistance or charge transfer resistance $\left(\mathrm{R}_{\mathrm{ct}}\right)$ and double layer capacitance $\left(\mathrm{C}_{\mathrm{p}}\right)$ of the thermal treated alloys.

\section{RESULTS AND DISCUSSION}

\subsection{Tensile Properties}

The typical UTS-strain rate curves of the alloys at $225{ }^{\circ} \mathrm{C}$ are plotted in Fig. 1. Strong work hardening happens during the tensile testing. To compare with the tensile behaviors of the alloys, typical tensile test experiments are conducted at three different strain rates $\left(10^{-4}, 10^{-3}\right.$ and $\left.10^{-2} \mathrm{~s}^{-1}\right)$. Enhancing strain rates results in an obvious increase in fracture strength. When the strain rates are below $10^{-3} \mathrm{~s}^{-1}$, work hardening decreases strongly. Work hardening decreases strongly during the plastic deformation of the sample at $10^{-4} \mathrm{~s}^{-1}$, and a necking phenomenon is observed at this strain rate before fracture. The tensile strength increases more pronouncedly with the increase of strain rates and $\mathrm{Cu}$ content. An alloy containing $0.5 \mathrm{wt} \% \mathrm{Cu}, \mathrm{Al}-6 \mathrm{Si}-$ $0.5 \mathrm{Mg}-0.5 \mathrm{Cu}$ shows higher ultimate tensile strength all over the strain rates.

Figure 2 indicates the yield strength $(0.2 \%$ proof strength) vs. strain rates of the alloys. The increase in proof strengths with the strain rates of the alloys is very similar to the ultimate tensile strengths. With the increase of strain rate, the maximum yield strength being attained at $10^{-2} \mathrm{~s}^{-1} . \mathrm{Cu}$ addition increases the yield strength with strain rates. The intermetallic particles could contribute a reinforcement effect in the Al alloy matrix. The higher yield strength is due to the effect of precipitation hardening and higher strain hardening.

Figure 3 demonstrates the variation of \% elongation with the strain rates of the alloys. It is observed that at the strain rate for which strength is maximum $\left(10^{-2} \mathrm{~s}^{-1}\right)$, the ductility values of the alloys pass through a minima. The ductility value of the Al-6Si- $0.5 \mathrm{Mg}-0.5 \mathrm{Cu}$ aged alloy is found to be higher than that of the $\mathrm{Cu}$-free alloy over all strain rates. 


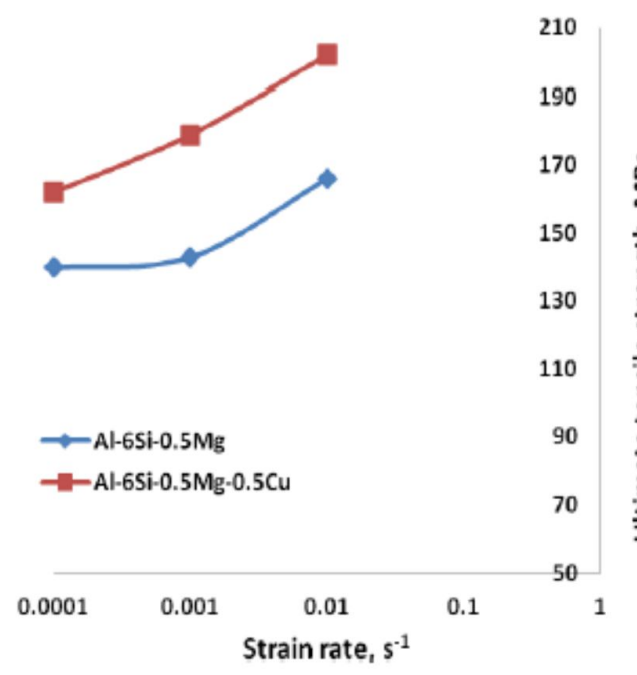

Fig. 1: Ultimate tensile strength-strain rate curves of investigated peak-aged alloys.

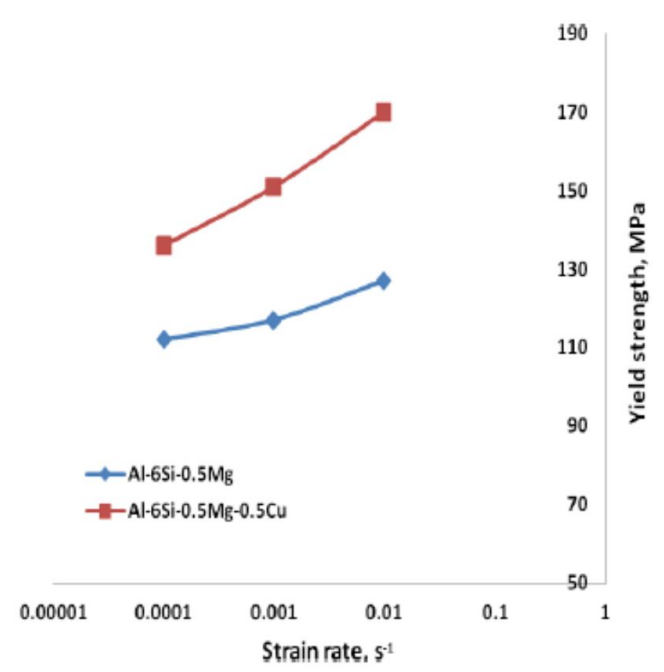

Fig. 2: Yield strength-strain rate curves of investigated peak-aged alloys.

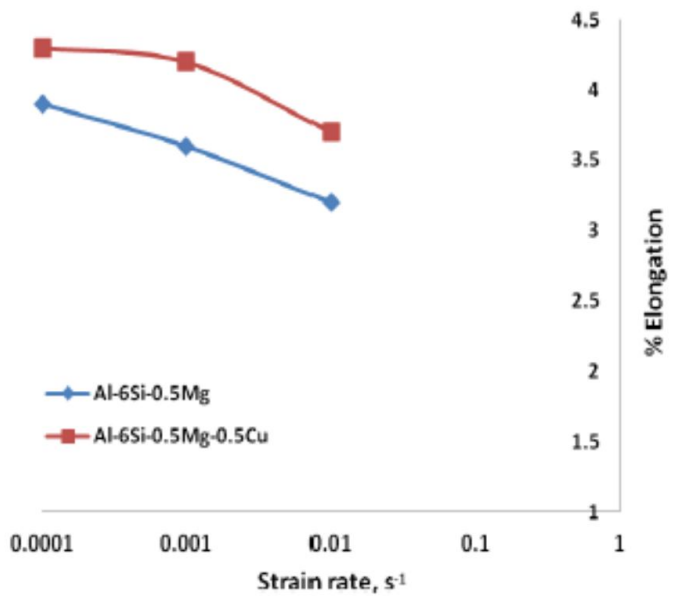

Fig. 3: Ductility (\%elongation) - strain rates curves of investigated peak-aged alloys.

Figures 4 and 5 show the SEM micrographs of the fracture surfaces of the Al$6 \mathrm{Si}-0.5 \mathrm{Mg}$ and $\mathrm{Al}-6 \mathrm{Si}-0.5 \mathrm{Mg}-0.5 \mathrm{Cu}$ alloy at various strain rates. $\mathrm{Cu}$ addition $(0.5$ wt $\%$ ) to $\mathrm{Al}-6 \mathrm{Si}-0.5 \mathrm{Mg}$ alloy increases the number of dimples and their sizes. $\mathrm{Cu}$ free Al-6Si-0.5Mg alloy shows the shallower dimples and many transcrystalline facet planes (Fig. 4a) but the $0.5 \mathrm{wt} \% \mathrm{Cu}$ content alloy (Fig. 5a) increases the depth of the dimples and their number. The deeper dimples at lower strain rate indicate ductile tearing. At the lower strain rate $\left(10^{-4} \mathrm{~s}^{-1}\right)$ the dimples are larger and deeper than the higher strain rates' $\left(10^{-3} \mathrm{~s}^{-1}, 10^{-2} \mathrm{~s}^{-1}\right)$ tensile testing samples. The cleavage facets (Fig. $5 \mathrm{~b})$ are mainly created at high strain hardening tensile testing.

\subsection{Electrochemical Corrosion Behavior}

Table 1 shows the Electrochemical Impedance Spectroscopy (EIS) test results. The open circuit potential (OCP) with exposure of aged Al-6Si-0.5Mg $(-0.5 \mathrm{Cu})$ alloys to simulated seawater is shown in Table 1 . The steady state OCP of the $\mathrm{Cu}$-free alloy is $-0.8454 \mathrm{~V}$ and it is the higher negative OCP value between the alloys under 

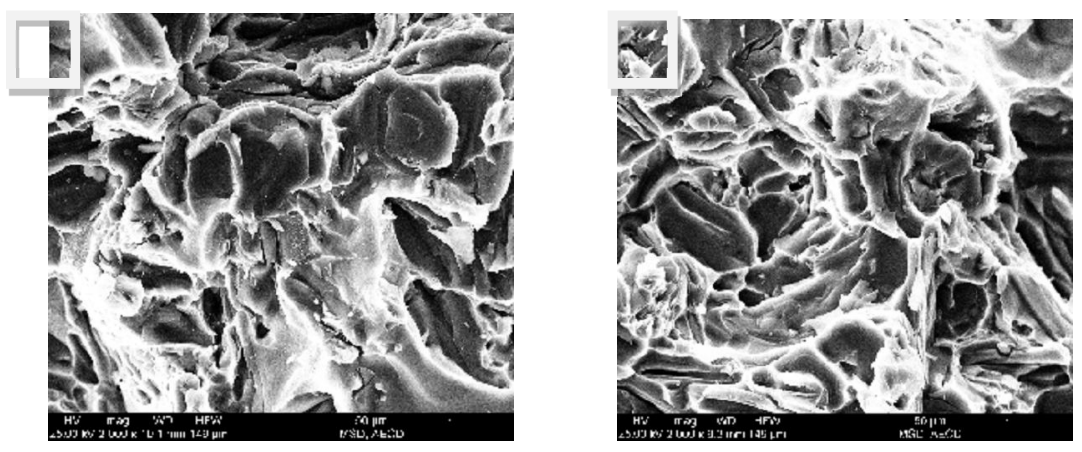

Fig. 4: Al-6Si-0.5Mg alloy SEM micrographs of fracture surfaces at the strain rates (a) $10^{-4} \mathrm{~s}^{-1}$; (b) $10^{-2} \mathrm{~s}^{-1}$.
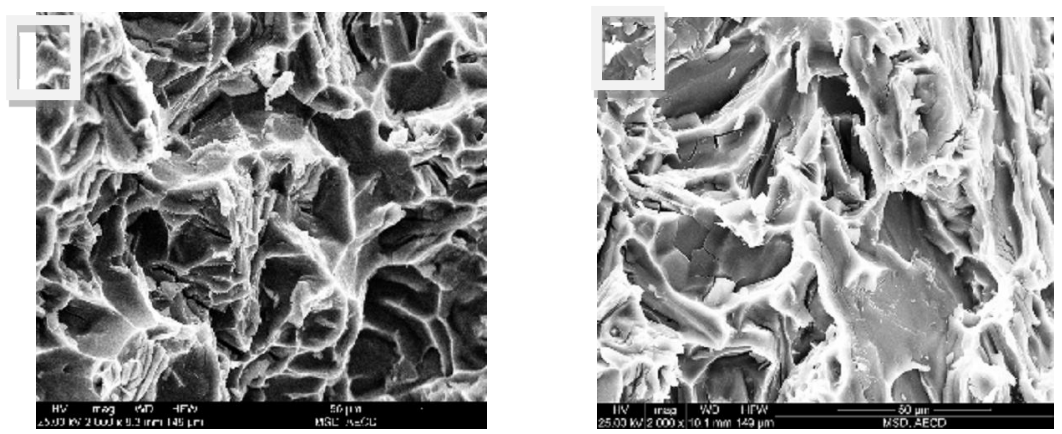

Fig. 5: Al-6Si-0.5Mg-0.5Cu alloy SEM micrographs of fracture surfaces at the strain rates (a) $10^{-4} \mathrm{~s}^{-1}$; (b) $10^{-2} \mathrm{~s}^{-1}$.

investigation. The occurrence of a positive shift in OCP in the Al-6Si-0.5Mg alloy containing $0.5 \mathrm{wt} \% \mathrm{Cu}$ indicates the existence of an anodically controlled reaction. The OCP values mainly depend on the chemical compositions and thermal history of the alloys.

Table 1: Impedance test results

\begin{tabular}{lrrrc}
\hline Alloy Compositions & \multicolumn{1}{c}{$\boldsymbol{R}_{\mathbf{s}}(\boldsymbol{\Omega})$} & \multicolumn{1}{c}{$\boldsymbol{R}_{\mathrm{ct}}(\mathbf{k} \boldsymbol{\Omega})$} & \multicolumn{1}{c}{$\boldsymbol{C}_{\mathrm{p}}(\boldsymbol{\mu} \mathbf{F})$} & OCP(V/SCE) \\
\hline $\mathrm{Al}-6 \mathrm{Si}-0.5 \mathrm{Mg}$ & 40.37 & 15.57 & 1.259 & -0.8454 \\
$\mathrm{Al}-6 \mathrm{Si}-0.5 \mathrm{Mg}-0.5 \mathrm{Cu}$ & 43.93 & 25.75 & 1.793 & -0.7037 \\
\hline
\end{tabular}

\subsection{Impedance Measurements}

The data obtained was modeled and the equivalent circuit that best fitted the experimental data is shown in Fig. 6. $\mathrm{R}_{\mathrm{s}}$ represents the ohmic solution resistance of the electrolyte. $R_{c t}$ and $C_{p}$ are the charge transfer resistance and electrical double layer capacitance respectively, which correspond to the Faradaic process at the alloy/media interface. Figure 7 shows the Nyquist diagrams (suggested equivalent circuit model shown in Fig. 6) of the Al-6Si-0.5 Mg $(-0.5 \mathrm{Cu})$ alloys in simulated seawater. In the Nyquist diagrams, the imaginary component of the impedance ( $\left.\mathrm{Z}^{\prime \prime}\right)$ 
against real part $\left(Z^{\prime}\right)$ is obtained in the form of a capacitive-resistive semicircle for each sample.

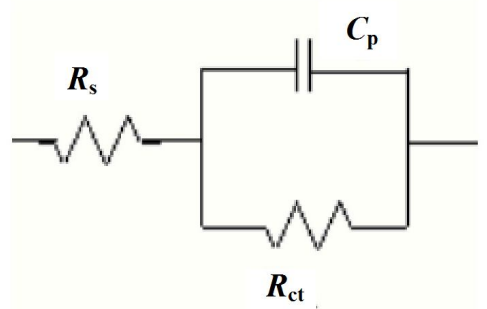

Fig. 6: Electrical equivalent circuit used for fitting of the impedance data of Al-6Si-0.5 Mg (-0.5 wt\% Cu) alloys.

The solution resistance $\left(R_{s}\right)$ of the alloys varies from 40-44 $\Omega$ (Table 1) and there are insignificant changes of $R_{s}$ values for the alloys during EIS testing. The $R_{s}$ values are negligible with respect to $R_{\mathrm{ct}}$ and the electrolyte behaves as a good ionic conductor. Impedance measurements showed that in simulated seawater, the addition of $0.5 \mathrm{wt} \%$ $\mathrm{Cu}$ in the Al-6Si-0.5Mg alloy increases the charge transfer resistance $\left(\mathrm{R}_{\mathrm{ct}}\right)$. For the $\mathrm{Cu}$-free $\mathrm{Al}-6 \mathrm{Si}-0.5 \mathrm{Mg}$ alloy, the charge transfer resistance $\left(\mathrm{R}_{\mathrm{ct}}\right)$ value in simulated seawater is $15.57 \mathrm{k} \Omega$, and this is increased to $25.75 \mathrm{k} \Omega$ with the addition of $0.5 \mathrm{wt} \%$ $\mathrm{Cu}$ into the Al-6Si-0.5Mg alloy. The increase in the charge transfer resistance indicates an increase in the corrosion resistance of the Al-6Si-0.5 Mg alloy with $\mathrm{Cu}$ addition. The double layer capacitance $\left(\mathrm{C}_{\mathrm{p}}\right)$ of the $\mathrm{Cu}$-free Al-6Si-0.5Mg alloy is $1.259 \mu \mathrm{F}$, which is the lower value between the alloys investigated. The double layer capacitance of Al-6Si-0.5Mg alloy increased to $1.793 \mu \mathrm{F}$ with the addition of 0.5 wt $\% \mathrm{Cu}$.

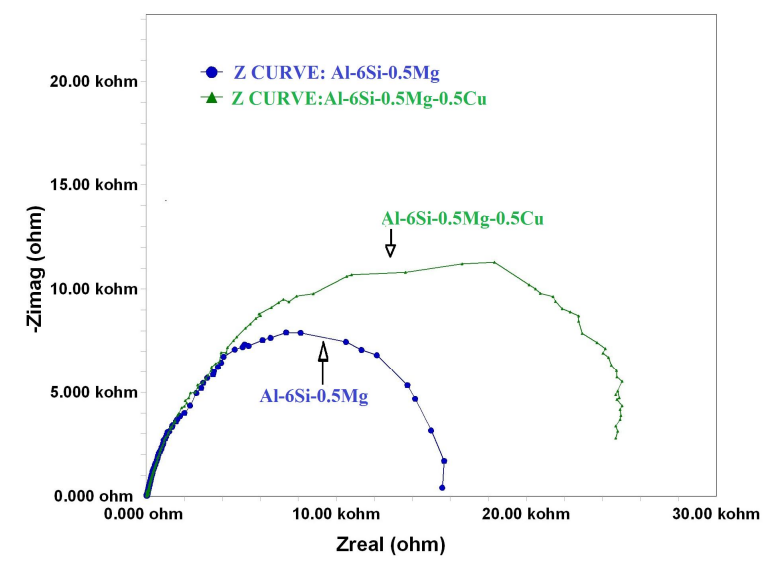

Fig. 7: Nyquist plots for the peak-aged $\mathrm{Al}-6 \mathrm{Si}-0.5 \mathrm{Mg}(-0.5 \mathrm{Cu})$ alloys.

Figure 8 shows the experimental EIS results in a Bode magnitude diagram for the Al-6Si-0.5 Mg $(-0.5 \mathrm{Cu})$ alloys. Bode plots show the total impedance behavior against applied frequency. At high frequencies, only the very mobile ions in solution are excited so that the solution resistance $\left(R_{s}\right)$ can be assessed. At lower-intermediate frequencies, capacitive charging of the solid-liquid interface occurs. The capacitive value $\mathrm{C}_{\mathrm{p}}$ can provide very important information about oxide properties when passivation or thicker oxides are formed on the surface. At low frequency, the capacitive charging disappears because the charge transfer of electrochemical 
reaction can occur and this measured value of the resistance corresponds directly to the corrosion rate. For this reason, this low frequency impedance value is referred to as polarization or charge transfer resistance $\left(R_{c t}\right)$. Table 2 shows the potentiodynamic polarization test results obtained from the electrochemical tests.

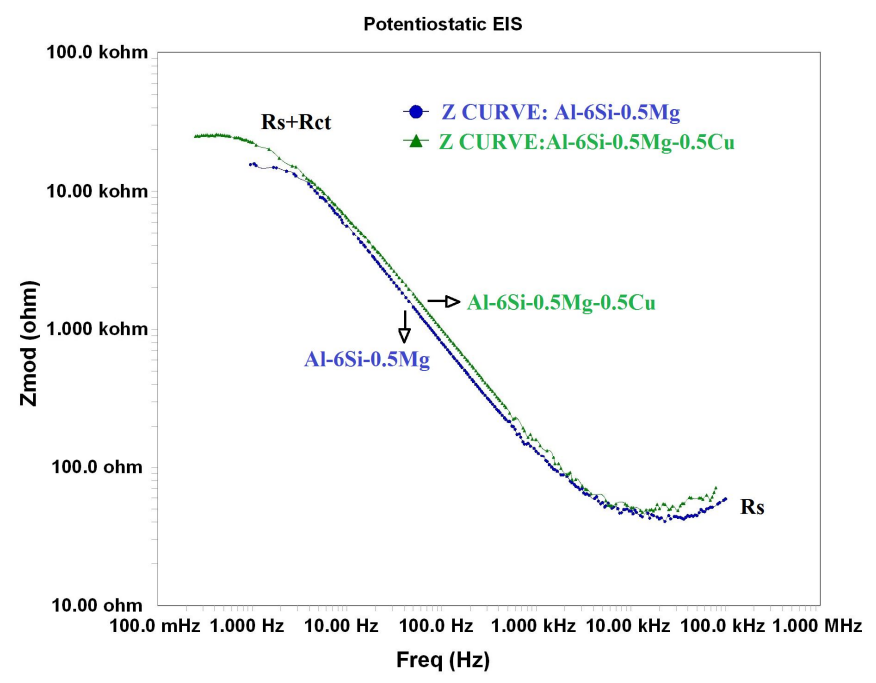

Fig. 8: Bode plots for the peak-aged Al-6Si-0.5Mg (-0.5Cu) alloys.

Table 2: Potentiodynamic polarization test results

\begin{tabular}{ccccc}
\hline Alloy & $\mathbf{I}_{\text {corr }}(\boldsymbol{\mu A})$ & $\mathbf{E}_{\text {corr }}(\mathbf{m V})$ & $\mathbf{E}_{\text {pit }}(\mathbf{m V})$ & Corrosion rate $(\mathbf{m p y})$ \\
\hline $\mathrm{Al}-6 \mathrm{Si}-0.5 \mathrm{Mg}$ & 6.300 & -764 & -480 & 5.287 \\
$\mathrm{Al}-6 \mathrm{Si}-0.5 \mathrm{Mg}-0.5 \mathrm{Cu}$ & 5.640 & -657 & -408 & 4.732 \\
\hline
\end{tabular}

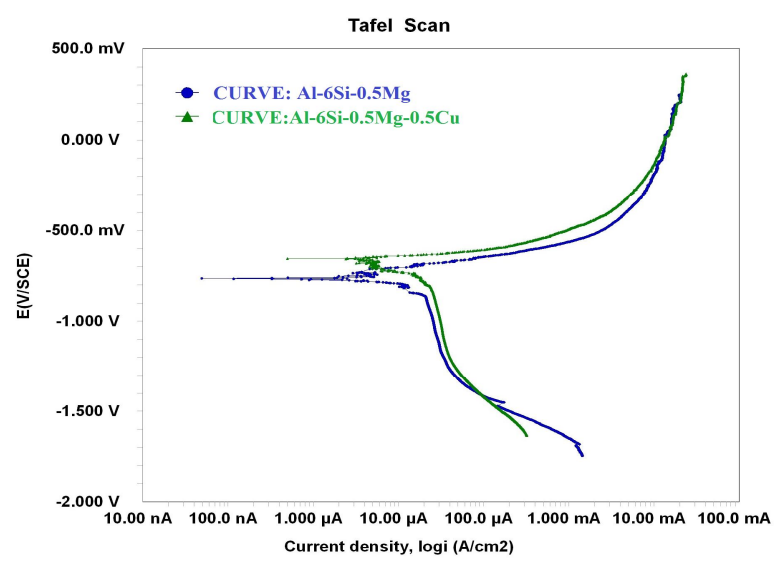

Fig. 9: Potentiodynamic polarization curves of peak-aged $\mathrm{Al}-6 \mathrm{Si}-0.5 \mathrm{Mg}(-0.5 \mathrm{Cu})$ alloys.

The potentiodynamic polarization curves for the Al-6Si-0.5Mg $(-0.5 \mathrm{Cu})$ alloys in simulated seawater are shown in Fig. 9. The anodic current density of the Al-6Si$0.5 \mathrm{Mg}$ alloy decreased with the $\mathrm{Cu}$ addition. This is caused by the slowing of the anodic reaction of the $\mathrm{Al}-6 \mathrm{Si}-0.5 \mathrm{Mg}-0.5 \mathrm{Cu}$ alloy. The addition of $\mathrm{Cu}$ caused the formation of micro-galvanic cells in the $\alpha$-aluminium matrix. The different 
intermetallic compounds (like $\mathrm{Mg}_{2} \mathrm{Si}, \mathrm{Al}_{2} \mathrm{Cu}$ etc.) led to the formation of microgalvanic cells because of the difference of corrosion potential between the intermetallics and the $\alpha$-aluminium matrix. It was well known that the addition of $\mathrm{Cu}$ increased the corrosion potential of a number of $\mathrm{Al}-\mathrm{Cu}-\mathrm{Si}$ alloys. For the $\mathrm{Cu}$-free $\mathrm{Al}$ $6 \mathrm{Si}-0.5 \mathrm{Mg}$ alloy, the corrosion potential was $-764 \mathrm{mV}$, which was the higher negative potential between the alloys investigated. With the addition of $0.5 \mathrm{wt} \% \mathrm{Cu}$, the corrosion potential of the Al-6Si-0.5Mg alloy shifted towards more positive values. Pitting potential $\left(\mathrm{E}_{\mathrm{pit}}\right)$ of the $0.5 \mathrm{wt} \% \mathrm{Cu}$ content alloy also shifted towards more positive values (from $-480 \mathrm{mV}$ to $-408 \mathrm{mV}$ ). Potentiodynamic tests showed that in simulated seawater, the addition of $\mathrm{Cu}$ into the $\mathrm{Al}-6 \mathrm{Si}-0.5 \mathrm{Mg}$ alloy decreased the corrosion current $\left(\mathrm{I}_{\mathrm{corr}}\right)$. For the $\mathrm{Cu}$-free $\mathrm{Al}-6 \mathrm{Si}-0.5 \mathrm{Mg}$ alloy, the corrosion current $\left(\mathrm{I}_{\text {corr }}\right)$ value in simulated seawater was $6.3 \mu \mathrm{A}$, and this decreased to $5.640 \mu \mathrm{A}$ with the addition of the $0.5 \mathrm{wt} \% \mathrm{Cu}$ to the Al-6Si-0.5Mg alloy. The corresponding corrosion rate decreased for the alloy (4.732 mpy) as well.

The microstructure of some selected as-corroded samples was observed under and scanning electron microscope (SEM). There was evidence of the corrosion products of the intermetallic compounds in all the samples examined. Besides, several pits were visible in all the samples examined. It is probable that the pits were formed by the intermetallics dropping out from the surface due to the dissolution of the surrounding matrix. However, it is also possible that the pits are caused by selective dissolution of the intermetallic particles of the second phase precipitates.

The forms of the corrosion in the studied Al-6Si- $0.5 \mathrm{Mg}(-0.5 \mathrm{Cu})$ alloys are not completely uniform and are predominantly comprised of pitting corrosion as obtained by the SEM. Samples were characterized by SEM following the potentiodynamic polarization tests. The peak-aged $\mathrm{Cu}$-free $\mathrm{Al}-6 \mathrm{Si}-0.5 \mathrm{Mg}$ alloy exhibited pits on their surface (Fig. 10), that had apparently nucleated randomly. Conversely, the exposed surface of the alloys exhibited a corrosion product covering the surface after polarization. There are more pits in the $\mathrm{Cu}$-free $\mathrm{Al}-6 \mathrm{Si}-0.5 \mathrm{Mg}$ alloy compared to the Al-6Si-0.5Mg-0.5Cu alloy. All the SEM micrographs (Fig. 10a and Fig. 10b) also showed that there was no corrosion in the fragmented and modified Al-Si eutectics.
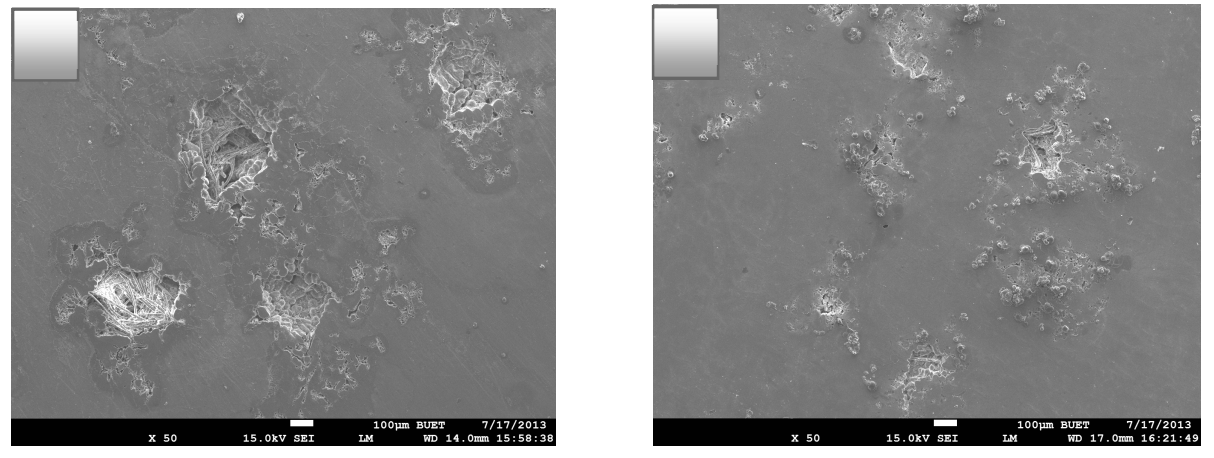

Fig. 10: SEM images show the damage surface morphology of as-corroded (a)Al$6 \mathrm{Si}-0.5 \mathrm{Mg}$ and (b) $\mathrm{Al}-6 \mathrm{Si}-0.5 \mathrm{Mg}-0.5 \mathrm{Cu}$ alloys.

\section{CONCLUSIONS}

The following conclusions could be drawn from the above results and discussions. 
- The addition of $0.5 \mathrm{wt} \% \mathrm{Cu}$ to the thermally treated $\mathrm{Al}-6 \mathrm{Si}-0.5 \mathrm{Mg}$ cast alloy resulted in improved tensile properties. The strain rate affects the ultimate tensile strength, yield strength, and ductility. The ultimate tensile strength and yield strength increased with decreasing strain rate but ductility decreased for the alloys. The Al-6Si- $0.5 \mathrm{Mg}-0.5 \mathrm{Cu}$ alloy shows better strength and improved ductility over all strain rates.

- The magnitude of the charge transfer resistance (corrosion resistance) value as an impedance parameter, increased with the addition of $0.5 \mathrm{wt} \% \mathrm{Cu}$ into Al$6 \mathrm{Si}-0.5 \mathrm{Mg}$ alloy. The electrochemical parameters obtained from polarization curves showed that the corrosion current ( $\mathrm{I}_{\text {corr }}$ ) and corrosion rate (mpy) decreased with the addition of $0.5 \mathrm{wt} \% \mathrm{Cu}$ into Al-6Si-0.5 Mg alloy. The open circuit potential $(\mathrm{OCP})$, corrosion potential $\left(\mathrm{E}_{\mathrm{corr}}\right)$ and pitting corrosion potential $\left(\mathrm{E}_{\mathrm{pit}}\right)$ were shifted in the more noble direction due to $0.5 \mathrm{wt} \% \mathrm{Cu}$ addition into $\mathrm{Al}-6 \mathrm{Si}-0.5 \mathrm{Mg}$ alloy. The microstructures studied indicate the pitting corrosion in the investigated alloys.

\section{REFERENCES}

[1] Kaufman JG, Rooy EL. (2004) Aluminium alloy castings, properties, processes and applications. ASM International.

[2] Ceschini L, Morri Al, Morri An, Pivetti G. (2011) Predictive equations of the tensile properties based on alloy hardness and microstructure for an A356 gravity die cast cylinder head. Mater. Des., 32:1367-1375.

[3] Jacobs MH. (1999) Precipitation Hardening, TALAT Lecture 1204, European Aluminium Association.

[4] Shivkumar S, Keller C, Apelian D. (1990) Aging behavior in cast Al-Si-Mg Alloys. AFS Transactions, 98:905-911.

[5] Lendvai J, Ungár T, Kovács I. (1974) The effect of the temperature of solution treatment and quenching on the zone formation process in Al-Mg-Si alloys. Mater. Sci. Eng., 16:8589.

[6] Dutta I, Allen SM. (1991) A calorimetric study of precipitation in commercial aluminium alloy 6061. J. Mater. Sci. Lett., 10:323-326.

[7] Barlow IC, Rainforth WM, Jones H. (2000) The role of silicon in the formation of the (A15Cu6Mg2) $\mathrm{r}$ phase in Al-Cu-Mg alloys. J. Mater. Sci., 35:1413-1418.

[8] Reif W, Yu S, Dutkiewicz J, Ciach R, Kro'1 J. (1997) Pre-ageing of AlSiCuMg alloys in relation to structure and mechanical properties. Mater. Des., 18:253-256.

[9] Mishra RK, Smith GW, Baxter WJ, Sachdev AK, Franetovic V. (2001) The sequence of precipitation in 339 aluminum castings. J. Mater. Sci., 36:461-468.

[10] Oosterkamp LD, Ivankovic A, Venizelos G. (1999) High strain rate properties of selected aluminium alloys. Mech. Sci. Eng. A, 278:225-235.

[11] Reyes A, Hopperstad OS, Lademo OG, Langseth M. (2006) Modeling of textured aluminum alloys used in a bumper system: material tests and characterization. Computational Mater. Sci., 37:246-268.

[12] Børvik T, Clausen AH, Eriksson M, Berstad T, Hopperstad OS, Langseth M. (2005) Experimental and numerical study on the perforation of AA6005-T6 panels. Int. J. Impact Eng., 32:35-64.

[13] Zor S, Zeren M, Ozkazance H, Karakulak E. (2010) Effect of Cu content on the corrosion of Al-Si eutectic alloys in acidic solution. Anti-Corrosion Meth. Mater., 57:185-191.

[14] Scamans GM, Hunter JA, Holroyd NJH. (1989) Corrosion of aluminium - a new approach. Proc. 8th Inter. Light Metals Congress, Leoban Wien, 699-705.

[15] Czechowski M. (2007) Effect of anodic polarization on stress corrosion cracking of some aluminium alloy. Adv. Mater. Sci., 7:13-20. 
[16] Svenningsen G, Larsen MH, Nordlien JH, Nisancioglu K. (2006) Effect of high temperature heat treatment on intergranular corrosion of $\mathrm{Al}-\mathrm{Mg}-\mathrm{Si}(\mathrm{Cu})$ model alloy. Corros. Sci., 48:258-272.

[17] Svenningsen G, Larsen MH. (2006) Effect of artificial aging on intergranular corrosion of extruded Al-Mg-Si alloy with small Cu content. Corros. Sci., 48:1528-1543.

[18] Svenningsen G, Larsen MH. (2006) Effect of thermomechanical history on intergranular corrosion of extruded AlMgSi(Cu) model alloy. Corros. Sci., 48:3969-3987.

[19] Svenningsen G, Lein JE, Bjorgum A, Nordlien JH, Nisancioglu K. (2006) Effect of low copper content and heat treatment on intergranular corrosion of model AlMgSi alloys. Corros. Sci., 48:226-242.

[20] Larsen MH, Walmsley JC. (2006) Significance of low copper content on grain boundary nanostructure and intergranular corrosion of $\mathrm{AlMgSi}(\mathrm{Cu})$ model alloys. Mater. Sci. Forum, 519-521:667-671.

[21] Zhan H, Mo JMC, Hannour F, Zhuang L, Terryn H, de Wit JHW. (2008) The influence of copper content on intergranular corrosion of model $\mathrm{AlMgSi}(\mathrm{Cu})$ alloys. Mater. Corros. 59:670-675. 